\title{
Moral Virtue as a Requisite for Illumination in the Platonic Tradition
}

\author{
Kristian Sheeley
}

check for updates

Citation: Sheeley, Kristian. 2021.

Moral Virtue as a Requisite for

Illumination in the Platonic Tradition. Religions 12: 838. https://doi.org/ $10.3390 /$ rel12100838

Academic Editors: Eva Anagnostou,

Georgios Steiris and

Georgios Arabatzis

Received: 27 August 2021

Accepted: 29 September 2021

Published: 8 October 2021

Publisher's Note: MDPI stays neutral with regard to jurisdictional claims in published maps and institutional affiliations.

Copyright: (C) 2021 by the author. Licensee MDPI, Basel, Switzerland. This article is an open access article distributed under the terms and conditions of the Creative Commons Attribution (CC BY) license (https:/ / creativecommons.org/licenses/by/ $4.0 /)$.
Department of Philosophy, University of Kentucky, Lexington, KY 40506, USA; Sheeleyk@uky.edu

\begin{abstract}
This paper traces the development of the idea that we must cultivate moral virtue in order to attain some degree of illumination regarding the nature of reality. I use the term "illumination" to cover a range of meanings intended by the philosophers I discuss, such as the "acquisition of wisdom" (Phaedo, 65a), the "sight" of divine beauty (Symposium, 210d-212b), or a mystical experience involving God or divine reality. Although this theme appears in many texts from the Platonic tradition, I focus on three major stages of its development. First, I show how Plato provides the basic framework of the idea that moral virtue is necessary for illumination, especially in his Phaedo and Symposium. Then, I explain how Plotinus synthesizes and substantially develops Plato's discussions of this idea. Finally, I discuss the Cappadocian Fathers' (Basil of Caesarea, Gregory of Nyssa, and Gregory Nazianzen) Christianization of this Platonic theme. In other words, Plotinus develops the basic framework of this argument first set forth by Plato, and the Cappadocians then adapt and modify Plotinus' views to fit their Christian commitments.
\end{abstract}

Keywords: virtue; conversion; Plato; Plotinus; Basil the Great; Gregory of Nyssa; Gregory Nazianzen; wisdom; beauty; purification

\section{Introduction}

To most modern thinkers, the ability to gain true insight into the nature of reality has little to do with the moral character of the person who searches for it. ${ }^{1}$ Instead, we assume that progress in metaphysics comes from creative thinking and rigorous argumentation. We suppose that reason has an innate capacity to find (at least some) solutions to metaphysical problems, and that reason need only find the right arguments or evidence to do so. Similarly, from a religious perspective, to some it may seem unusual to maintain that one's ability to experience divine presence, whether through mystical experience or the sense of inner elevation felt through certain types of religious practice, depends on the state of her character. Thus, the idea that our virtue or vice has an influence on the degree to which we can comprehend the nature of reality appears counterintuitive to many of us. Nonetheless, the Western version of this idea is rooted in Plato's corpus, and it plays no small role in the development of Western philosophical and religious thought.

This paper traces the development of the idea that we must cultivate moral virtue in order to attain some degree of illumination regarding the nature of reality. I use the term "illumination" to cover a range of meanings intended by the philosophers I discuss, such as the "acquisition of wisdom" (Phaedo, 65a), the "sight" of divine beauty (Symposium, 210d-212b), or a mystical experience involving God or divine reality. Although this theme appears in many texts from the Platonic tradition, I focus on three major stages of its development. First, I show how Plato provides the basic framework of the idea that moral virtue is necessary for illumination, especially in his Phaedo and Symposium. ${ }^{2}$ Then, I explain how Plotinus synthesizes and substantially develops Plato's discussions of this idea. Finally, I discuss the Cappadocian Fathers' (Basil of Caesarea, Gregory of Nyssa, and Gregory Nazianzen) Christianization of this Platonic theme. In other words, Plotinus develops the basic framework of this argument first set forth by Plato, and the Cappadocians then 
adapt and modify Plotinus' account to fit their Christian commitments. ${ }^{3}$ Further, all of the illumination experiences discussed by these authors can serve to either convert the person pursuing virtue to a better way of life or to renew a commitment she has already made to it, and Plotinus even uses the term "conversion" (epistrapheisa) explicitly in this context. ${ }^{4}$ My paper does not exhaust this rich topic, nor does it discuss every place where it occurs in ancient and medieval philosophy - it simply aims to show the roots of the idea as they appear in two Platonic dialogues and to examine two significant ways that later thinkers in the platonic tradition develop Plato's suggestions.

\section{Plato's Phaedo and Symposium}

As is the case with all of Plato's dialogues, the Phaedo and the Symposium are complex texts that pose numerous interpretive difficulties. It is unlikely that we can properly assess the significance of one part of the given text's discussion without taking the whole into view. However, since it falls far outside the scope of this paper to engage with all aspects of even one of these dialogues, I will limit my discussion to the task of explaining how the basic model of the idea that moral virtue is a requisite for illumination emerges in each text. Moreover, I will not attempt to reconstruct Plato's final view on this subject, since my goal is only to show how these dialogues offer a conceptual framework that is developed and modified by later thinkers in the Platonic tradition.

Toward the beginning of Socrates' discussion with Cebes, Simmias, and the other characters present in the Phaedo, Socrates states that he wants to give an "account" to show why "a man who has genuinely spent his life in philosophy" should be "confident about his imminent death, and to be optimistic that he'll win the greatest goods there, after he's met his end" (63e-64a). ${ }^{5}$ Socrates then famously claims that "the sole pursuit of those who correctly engage in philosophy is dying and being dead," and that it would be absurd for the philosopher who has spent his life "dying" to fear bodily death when it finally arrives (64a). If death is "the separation of the soul from the body" (64c), then philosophers try to "die" in the sense that they aim to "escape" (65d) from the body to attain "wisdom itself" (autēn tēn tēs phronēseōs) (65a9). Socrates states:

For if it is impossible to have pure knowledge [katharōs gnōnai, 66e5] of anything when we are in the company of the body, then either knowledge cannot be acquired anywhere, or it can be acquired when we are dead. For then the soul will be alone by itself, apart from the body, whereas before then it will not. And in the time when we are alive, it seems that we will be closest to knowledge if, so far as possible, we have no dealings with the body and do not associate with it except when absolutely necessary, and are not infected with its nature, but instead keep pure from it, until the god himself releases us. If we stay pure in this way by being separated from the body's folly, in all likelihood we will be with people of this kind, and will know through our very selves everything that is unalloyed, which is, equally, the truth. For it may be that it is not sanctioned for someone impure to grasp something pure. (66e-67b)

Regardless of whether Socrates purposely exaggerates this dichotomy between the body as the source of impurity and the soul as naturally pure, ${ }^{6}$ he introduces the idea that the soul must be in a state of moral purity to attain wisdom, or, as he also says, "the truth" and "pure knowledge." He uses the image of "escaping" the body to make the point that one must achieve a certain degree of moral perfection to become capable of receiving knowledge of the most perfect objects. Socrates suggests at $65 \mathrm{~d}-66 \mathrm{a}$ that the "purified" soul knows the Forms, naming Justice, Beauty, Goodness, Largeness, Health, Strength as examples. His statements entail that we must become like that which we strive to know-since the Forms (or the truth, as he says above) are "unalloyed" and pure, our souls too must become pure if we want to attain such knowledge. ${ }^{7}$

Socrates then explains that cultivating the virtues-wisdom, courage, temperance, and justice-is the way to "purify" or "separate" the soul from the body. Indeed, seeking 
to separate the soul from the body is the only way to develop authentic virtue. Only the philosopher acquires genuine courage and temperance:

[... ] if you see that a man is resentful that he is about to die, is that sufficient proof for you that he was not a lover of wisdom but a sort of body-lover? And this same man, I take it, is also a money-lover and honor-lover, either one of these or both. [ ... ] and doesn't that which is called 'courage' also belong most to those with this attitude? [ ... ] And temperance as well-that which even ordinary people call 'temperance,' namely not being in a flutter about one's desires, but rather being disdainful towards them and staying composed—doesn't that belong only to those who particularly disdain the body and live in philosophy? (68b-c)

In the context of this discussion, the philosopher is perfectly courageous because he does not value his life, body, or honor more than virtue. Since he is already seeking to separate his soul from his body, he does not hesitate to risk his bodily life for the sake of virtuous action. Likewise, the philosopher does not simply forgo some pleasures for the sake of others that he desires more (68e-69a), a quality which is merely "called" temperance by most people (and one which Socrates calls an "illusion" of virtue "fit for slaves" at $69 \mathrm{~b}-\mathrm{c})$. Rather, the philosopher remains "composed" and unconcerned with the body so far as possible in his pursuit of wisdom, "disdaining" it insofar as it interferes with this pursuit. ${ }^{8}$ Further, the philosopher must achieve these virtues by "habituating" himself to give up his attachment to the body: "And doesn't purification turn out to be the very thing we were recently talking about in our discussion, namely parting the soul from the body as much as possible and habituating it to assembling and gathering itself from every part of the body, alone by itself [ ... ]?" (67c-d). Again, while it is difficult to determine the specific meaning of these passages or to decide how literally they should be taken in the context of the Phaedo, it is at least clear that the habitual pursuit of virtue is necessary for the soul to arrive at truth.

The Symposium's discussion of the idea that moral virtue is necessary for some sort of illumination shares notable similarities and differences with the Phaedo passages discussed above. When Socrates retells the discussion that he had in his youth with Diotima, the priestess from Mantinea, we learn that their discussion itself is a kind of "initiation" involving several stages of preparation for a final goal: "'Even you, Socrates, could probably come to be initiated into these rites of love. But as for the purpose of these rites when they are done correctly - that is the final and highest mystery, and I don't know if you are capable of it. I myself will tell you,' she said, 'and I won't stint any effort. And you must try to follow if you can'" (210a)..$^{9}$ According to Diotima, people such as young Socrates must put forth effort to become "capable" of understanding or somehow partaking of what she provocatively refers to as the "final and highest mystery." Although she does not explicitly say in this passage that Socrates must morally cultivate himself to prepare for the highest mystery, this comment prefigures her later discussion of moral transformation as it relates to experiencing divine beauty.

In the famous "ladder of love" passage, Diotima outlines several stages a soul moves through on its way toward both a vision of Beauty itself and the attainment of "true" (alêthē) virtue (212b). Much like Socrates' discussion of virtue as purification in the Phaedo (67a-69d), Diotima suggests that one's moral character is shaped by whatever he loves most. In other words, the lover ascends each rung of the ladder, so to speak, by finding a new primary beloved object, and each of these objects leads the soul closer to Beauty itself and true virtue. The lover who ascends the ladder by loving "in the right order and correctly" comes to love the beauty of virtuous activities, laws, and knowledge, and he eventually acquires a "love of wisdom," or philosophia (210c-d). As a result, he avoids the inordinate love for lower goods that leads to vice. The lover is "strengthened" at each stage:

The result is that he will see the beauty of knowledge and be looking mainly not at beauty in a single example - as a servant would who favored the beauty of a little boy or a man or a single custom (being a slave, of course, he's low and 
small-minded)—but the lover is turned to the great sea of beauty, and, gazing upon this, he gives birth to many gloriously beautiful ideas and theories, in unstinting love of wisdom, until, having grown and been strengthened there, he catches sight of such knowledge, and it is the knowledge of such beauty [ ... ] the man who has been thus far guided in matters of Love, who has beheld beautiful things in the right order and correctly, is coming now to the goal of Loving: all of a sudden he will catch sight of something wonderfully beautiful in its nature; that, Socrates, is the reason for all his earlier labors ... (210d-211a)

The lover "catches sight" of the "great sea of beauty" only after his soul has been "strengthened" at each stage of his ascent. ${ }^{10}$ He would not be able to suddenly "catch sight of something wonderfully beautiful in its nature"- "the divine Beauty itself" (211e) without the "earlier labors" that prepared his soul for this vision. His love of the souls, ideas, knowledge, laws, and activities that "make young men better" (210c) has brought him closer to true virtue. However, before viewing Beauty itself, he has not yet "given birth" (212a) to true virtue and thus has not become as virtuous as possible.

The vision of Beauty itself has a transformative impact on the soul, completing its process of becoming as good as possible through virtue. Using the language of pregnancy from her earlier discussion of immortality, Diotima claims that the soul can give birth to true virtue after it gazes at Beauty itself: "[ ... ] in that life alone, when he looks at Beauty in the only way that Beauty can be seen-only then will it become possible for him to give birth not to images of virtue (because he's in touch with no images), but to true virtue (because he is in touch with the true Beauty)." (211e-212b). Though it is unclear exactly what Diotima means by "images of virtue," it is at least safe to infer that the lover begins the process of becoming virtuous at earlier stages in his ascent toward divine beauty, as the passages cited above indicate. The soul who would ascend to the top the ladder must make significant progress in cultivating virtue if it is to become capable of seeing Beauty itself, and this vision in turn completes its transformation by allowing it to attain and "nourish" true virtue.

\section{Plotinus' Enneads I.2}

Plotinus' treatise "On Virtues" (Ennead I.2) interprets and systematizes many discussions of virtue throughout Plato's corpus. He makes a clear distinction between two "kinds" of virtues, namely the "lower" (or "civic") virtues and the "higher" virtues. Importantly, much of his analysis relies on the concept of "becoming like God" (homoiōsis theōi) expressed in the famous "digression" passage of the Theaetetus (176a-b). Plotinus claims that the lower virtues purify the soul and thus begin the process of deification. In doing so, he also gives a concise definition of each civic virtue:

Plato, when he speaks of 'likeness' as a 'flight to God' from existence here below, and does not call the virtues which come into play in civic life just 'virtues,' but adds the qualification 'civic,' and elsewhere calls all the virtues 'purifications,' makes clear that he postulates two kinds of virtues [ ... ] What then do we mean when we call these other virtues 'purifications,' and how are we made really like [God] by being purified? Since the soul is evil when it is thoroughly mixed with the body and shares its experiences and has all the same opinions, it will be good and possess virtue when it no longer has the same opinions but acts alone- - this is intelligence and wisdom — and does not share the body's experiences—-this is selfcontrol —and it not afraid of departing from the body — this is courage - and is ruled by reason and intellect, without opposition-and this is justice. (I.2.3 6-19)

Plotinus' conception of evil as the result of the soul being "thoroughly mixed with the body" and virtue as the dissolution of this mixture calls to mind Socrates' account of virtue as purification in the Phaedo. Each of the virtues frees the soul from the limitations and imperfections imposed by the body. The more virtuous a soul becomes, the less it is ruled by the body and its opinions, experiences, or overall influence. Since the two 
highest hypostases-the Intellect and the One-are not "mixed" with matter for Plotinus, the individual soul becomes more like them the less it is influenced by the body. Indeed, we are the Intellect in an important sense, since our souls emanate from this higher reality, and the form of each person resides in the Intellect. Our fixation on the body, though, prevents us from regaining our true nature. ${ }^{11}$ Further, the civic virtues "genuinely set us in order and make us better by giving limit and measure to our desires, and putting measure into all our experience; and they abolish false opinions" (I.2.2 14-16). Since matter in itself completely lacks measure for Plotinus, while on the other hand the One is the ultimate source of measure, our souls become more like the One thanks to the measure imposed on us by virtue.

Plotinus later defines "the higher virtues" with a view toward the individual's relation to the Intellect. That is, the higher virtues allow the individual to contemplate and identify with Intellect through an act of noessis. ${ }^{12}$ The lower kind of wisdom rids the individual soul of its false opinions and influence from the body and thus prepares the individual to attain "higher" wisdom, through which it performs the Intellect's self-reflexive act of understanding. ${ }^{13}$ Hence, he says that higher wisdom "consists in the contemplation of that which Intellect contains" (1.2.6 13-14). Plotinus defines the other virtues in a similar manner: "So the higher justice in the soul it is activity toward Intellect, its self-control is its inward turning to intellect, its courage is its freedom from affections, according to the likeness of that to which it looks which is free from affections by nature" (1.2.6 23-27). Moreover, Plotinus holds that to have one virtue entails having them all: "These virtues in the soul, too, imply one another reciprocally, in the same way as the exemplars (so to call them) There in the Intellect which are prior to virtue. For intuitive thought [noessis] There is knowledge and wisdom, self-concentration is self-control, its own proper activity is 'minding its own business;' its equivalent to courage is immateriality and abiding pure by itself" (I.2.7 1-7). ${ }^{14}$ The soul who achieves higher virtue possesses all four cardinal virtues in the single act of noessis, since the forms of each virtue are really the same activity of the Intellect considered from four different perspectives-while they manifest as four different virtues in the soul, they are a single activity in the highly unified Intellect.

Once an individual purifies herself by cultivating the lower virtues, he gains the capacity to experience the Intellect's characteristic act of noēsis. Significantly, Plotinus calls the individual's ascent to the Intellect a "conversion":

So [the purified soul's] good will be fellowship with that which is akin to it, and its evil fellowship with its opposites. Then it must attain to this fellowship after being purified; and it will do so by a conversion [epistrapheisa]. Does it then turn itself after the purification? Rather, after the purification it is already turned. Is this, then, its virtue? It is rather that which results for it from the conversion. And what is this? A sight and the impression of what is seen, implanted and working in it, like the relationship between sight and its object. (1.2.4 15-20)

The purified soul who has developed the lower virtues can experience a conversion, whereby it gains a "fellowship" or unification with its superior source, the Intellect. This unification occurs when the purified soul participates in the higher virtues in the act of noessis, through which the Intellect reflexively understands itself and its many forms. ${ }^{15}$ In other words, the higher virtues allow for a noetic vision or understanding of divine reality, and although embodied humans can experience them for short intervals, we cannot constantly live the life of the Intellect, so to speak. Much like Symposium 212a-b where the vision of divine beauty allows the purified soul to give birth to true virtue, for Plotinus the purified soul is already "turned" toward the intellect thanks to its civic virtue, but then the "sight and impression of what is seen" (i.e., the Intellect and its many forms) "results" in the attainment of the higher virtues. 


\section{The Cappadocian Fathers}

Fourth century Christian philosophers Basil of Caesarea, Gregory of Nyssa, and Gregory Nazianzen produced a sophisticated Christian development of Platonic ideas pertaining to virtue's role as a requisite for illumination. I interpret the Cappadocians as collectively arguing that vicious, excessive desires for earthly goods such as bodily goods, pleasure, wealth, and honors are mutually exclusive with divine love (agape) as well as the experience of spiritual, ecstatic union with God that sometimes accompanies this type of love. Indeed, one's cultivation of a moderate, healthy desire for earthly goods allows the soul to gain more complete inner union with God through divine love. ${ }^{16}$ Developing virtue and magnifying one's own love for God together perpetuate the process of deification (theōsis). Their treatment of this topic modifies Plotinus' discussion in Ennead 1.2 by asserting that God assists deification by actively granting grace to those who rightly pursue virtue. More specifically, the Cappadocians characterize humanity as playing a passive role in one respect and an active role in another insofar as humans must deliberately develop their moral virtue while simultaneously relying on God's grace as a necessary aid. This final section discusses the Cappadocians' view that theosis is fueled by both the soul's development of virtue and its communion with God's transformative presence.

In On the Holy Spirit, Basil outlines a process of spiritual progression that begins with self-purification through controlling "the passions" and ultimately leads to "illumination by the Spirit"17. Basil uses language evoking Genesis 1:26 where mankind is created in God's image, and he suggests that we must "restore" this image from our current sinful state:

This association [of the Holy Spirit with the soul] results from the withdrawal of the passions which, coming afterwards gradually on the soul from its friendship to the flesh, have alienated it from its close relationship with God. Only then after a man is purified from the shame whose stain he took through his wickedness, and has come back again to his natural beauty, and by as it were cleansing the royal image and restoring its ancient form-only thus is it possible for him to draw near to the Paraclete. ${ }^{18}$

"Cleansing" the soul is described as "withdrawing the passions," whose sway over the soul "results" from its "friendship to the flesh." That is, by becoming preoccupied with the goods of the flesh such as pleasure, wealth, and so forth, the soul becomes more and more invested in or entangled with the flesh. Since the body is the home of the passions, the soul's love of bodily goods entails a high degree of attachment to the body, which in turn entails a higher degree of subjugation to the throes of bodily desire and emotions. These bodily passions are classically associated with the desire for wealth as well as the pride of reputation, both of which "stain" the soul by further solidifying its attachment to bodily goods. So, if one's soul moderates its "association" with the body, it then becomes capable of "nearer" association with the Holy Spirit.

While Basil's description of the soul's purification process is closely akin to Plotinus' in the aforementioned respects, he Christianizes Plotinus' account by adding that the Holy Spirit must play a guiding role in any successful process of deification. Basil continues his discussion quoted above:

And He, like the sun, will by the aid of your purified eye show you in Himself the image of the invisible, and in the blessed spectacle of the image you shall behold the unspeakable beauty of the archetype. Through His aid hearts are lifted up, the weak are held by the hand, and they who are advancing are brought to perfection. Shining upon those who are cleansed from every spot, He makes them spiritual by fellowship with Himself. Just as when a sunbeam falls on bright and transparent bodies, they themselves become brilliant too, and shed forth a fresh brightness from themselves, so souls wherein the Spirit dwells, illuminated by the Spirit, themselves become spiritual, and send forth their grace to others. Hence comes [ ... ] joy without end, abiding in God, being made like to God, and, highest of all, being made God. ${ }^{19}$ 
For Basil, God plays an active role in both stages of the soul's deification. First, God's "aid" "lifts up" the believer's "heart" and holds it "by the hand," implying that God's grace assists humans to realize the "perfection" of moral virtue if they have sufficient desire for it. In doing so, God makes the perfected soul "spiritual" (rather than "fleshly") through "fellowship with Himself," which suggests that the Holy Spirit's presence transforms the soul to become more like itself. Secondly, the "purified eye" of the perfected soul may, with the active aid of the Holy Spirit once again, perceive the "unspeakable beauty of the archetype" in an "image of the invisible." God's initial facilitation of the soul's purification subsequently gives rise to its higher degree of kinship with God as well as inward access to divine beauty. The "highest" stage in this process of growing more similar to God constitutes complete deification or "being made God." The extent to which becoming God is possible for a human soul, though, is unclear. ${ }^{20}$

Basil then further explains how the soul's access to the Holy Spirit's presence depends upon the extent to which its character is "stable" and pure. He draws an analogy to bodily health to illustrate his claim: "Furthermore as in our bodies health, or heat, or other variable conditions can be present at some times more than at others, so too the Spirit often exists in the soul; for He does not remain with those who, on account of the instability of their character, lightly reject the grace which they have received." 21 An unstable character is marked by "rejecting" in some way the "grace" God provides along the road to purification. ${ }^{22}$ In other words, if the soul does not actively maintain ${ }^{23}$ its virtue, it loses its capacity to receive and abide in the Holy Spirit, which also diminishes the grace necessary to inwardly perceive God's beauty. Hence, although Basil's account of the soul's deification process recognizes a necessity for God's aid, he maintains that the soul can never cease to put forth its own effort into maintaining the purificatory virtues if it desires to properly cultivate its kinship with the Holy Spirit.

In Gregory of Nyssa's On Virginity, we find passages arguing that virtue and vice at least partly stem from one's ability (or lack thereof) to distinguish between true and merely apparent beauty. In his discussion of beauty that in many respects mirrors the "ladder of love" passage in the Symposium and Plotinus' Enneads 1.6 "On Beauty," Gregory argues that the intensity of love one feels for a given good directly follows from the extent to which he regards it as beautiful:

If anyone wants to know the exact source of all the false and pernicious conceptions of beauty, he will find it in nothing other than our failure to have 'our senses exercised to discern that which is beautiful from that which is not' (Heb. 5:14). Owing to this men give up all search after that which is truly good. Some sink down into a love of the flesh; others turn their desires to lifeless material possessions; others limit their idea of beauty to worldly honor, glory, and power. Others still are enthusiastic about art and science. The most debased make their palate and their stomach the test of what is good. ${ }^{24}$

Presumably, proper life experience and education from religion ${ }^{25}$ or philosophy play a role in, as Paul's Letter to the Hebrews puts it, "exercising the senses" to "discern" true ${ }^{26}$ and false beauty. Those who "sink down into a love of" this or that earthly good (food, sex, material wealth, honor, or sciences) do so because they erroneously perceive these goods as beautiful in the highest degree. Without external human help or the divine grace that helps to "turn" us away from "obsession with appearances" and "fleeting pleasures", we remain entrenched in our "material way of thinking".

Much like Basil, Gregory of Nyssa emphasizes God's active role in assisting the soul's deification process. Gregory strictly delineates the extent to which human agency plays a part in developing the purificatory virtues:

Yet this is not possible to achieve unless one is created anew. Our restoration to likeness to the divine is not our own work, nor is it the product of human ability, but it belongs to the generosity of God who freely, at the birth of the first man, gave our nature a likeness to Himself. Human effort extends only to this: the 
removal of the filth which has accumulated through evil and the bringing to light again of the hidden beauty in the soul. ${ }^{27}$

Being "created anew" implies that the soul must passively receive the necessary means for deification or "restoration" to "likeness to the divine" from God. If the believer invests her "effort" to "remove the filth" of vice from her soul, then God's generosity will likewise become available to lighten her burden along the way. Furthermore, Gregory develops his pagan and Christian predecessors' collective discussion of deification by introducing his account of perpetual advancement into God (epektasis). ${ }^{28}$ He writes:

Once [the soul] is released from its earthly attachment, it becomes light and swift for its movement upward, soaring from below up to the heights. If nothing comes from above to hinder its upward thrust (for the nature of the Good attracts to itself those who look to it), the soul rises ever higher and will always make its flight yet higher. By its desire of the heavenly things it "strains ahead for what is still to come" (Phil. 3:13), as the Apostle says. Made to desire and not to abandon the transcendent height by the things already attained, it makes its way upward without ceasing, ever through its prior accomplishments renewing its intensity for the flight.

Because the soul is "made" by God such that it desires the good or the beautiful unconditionally, the deification that began by reorienting one's desire through virtue will ideally continue in a cyclical manner without end. Each stage of progress "renews the intensity of its flight," since insight into God (or "the Good") paradoxically overwhelms the soul with satisfaction while also augmenting its attraction and intensity of desire for God.

Having discussed the purification process necessary for spiritual illumination, I will now briefly interpret the Cappadocians' remarks about the inner experience I refer to as "spiritual illumination" that they think a purified soul can undergo. The Cappadocians discuss noetic, ${ }^{29}$ mystical, or ecstatic spiritual encounters with the divine that seize a virtuous person when she practices prayerful meditation or other contemplative activities. First, Gregory Nazianzen speaks about the nature of man's intermittent inner contact with God's presence, which remains elusive even to those who have trained themselves through virtue:

For in Himself He sums up and contains all being, having neither beginning in the past nor end in the future; like some great sea of being, limitless and unbounded, transcending all conception of time and nature, only adumbrated by the mind, and that very dimly and scantily - not from the things directly concerning Him, but from the things around Him; one mental image being received from one source and another from another, and combined into some sort of presentation of the truth, which escapes us when we have caught it, and takes to flight when we have conceived it, blazing forth upon our master-part [i.e., the mind], even when that is cleansed, as the lightning flash which will not stay its course does upon our sight. ${ }^{30}$

As the mind contemplates God in an effort to gain access to Him, we form mental "images" of Him that are based on beautiful creations that we have come to know through the senses. Such contemplation may lead us to arrive at "some sort of presentation of the truth"; yet, however dazzling this representation might be, God's "limitless and unbounded" nature that "transcends all conception" means that the human mind can only "dimly" fathom God. Moreover, the mind can hold its dim representation of God only briefly before it "blazes forth" from our mental "sight." God's elusive nature, then, serves to increase the soul's desire for God, perpetuating the cycle of purification and the subsequent insight into divine beauty discussed by Gregory of Nyssa above.

Returning once more to Gregory of Nyssa's On Virginity, we find familiar Platonic imagery of light and sight ${ }^{31}$ to describe inner noetic or spiritual experiences. He writes: 
I dare say that it is to such a person, who has purified all the powers of his soul from every form of evil, that that which is alone beautiful by nature becomes evident. Just as the eye cleansed from rheum sees objects shining brightly in the distance in the air, so also the soul through incorruptibility acquires the power to perceive the Light. The goal of true virginity and zeal for incorruptibility is the ability to see God, for the chief and first and only Beautiful and Good and Pure is the God of all ..." "32

Although the "Light" never hides itself since it does not change, "evils" often inhibit or obscure the soul's "powers" such that they cannot perceive it. When the evils are "cleansed" like "rheum" from the eye, the soul becomes truly "virgin" or pure and therefore possesses a "zeal for incorruptibility." Such a person can finally "see God," which suggests that she inwardly perceives God with the mind as an overwhelmingly beautiful, permeating presence. Gregory describes a similar sort of union with God at a different point in the text, but there he gives more detail to the state of the soul during its contact with the divine beauty: "Having come close to Beauty, he will become beautiful himself. Through his participation in the true light, he will himself be in a state of brightness and illumination." 33 The light's beauty transforms the soul "participating" 34 in it to enter a "state of brightness and illumination," meaning that contact with divine beauty transforms (either temporarily ${ }^{35}$ or permanently) the soul into a better, more divine being.

\section{Conclusions}

While there is much more to be said about the many explorations of virtue's effects on the soul throughout the Platonic tradition, this paper has flagged several significant ways this topic has been construed and expressed. The stages of development in these ancient discussions of moral virtue are both interesting in their own right and highly relevant to those who live philosophically in the ancient Greek sense of the term. The ancients remind us that the pursuit of wisdom involves all spheres of our lives, and that these spheres do not remain isolated from one another. Not only do they offer reasons to pursue virtue for its own sake or for its effect on our quality of life, but they also point out that a change in character shapes our minds such that we might discover aspects of reality that are currently concealed from us.

Funding: This research received no external funding.

Institutional Review Board Statement: Not applicable.

Informed Consent Statement: Not applicable.

Data Availability Statement: Not applicable.

Conflicts of Interest: The author declares no conflict of interest.

\section{Notes}

1 Hadot $(2002,1995)$ is, of course, well known for bringing this crucial theme in ancient philosophy to the attention of contemporary readers with his excellent writings on philosophy as a way of life. Another famous modern scholar of this theme is Foucault, who summarized it by saying that (Foucault et al. 2001, p. 27) "there cannot be knowledge without a profound modification of the subject's being".

2 There are several other passages in Plato's corpus where this idea may be found. For example, Republic VII's discussion of the training that the guardians must undergo before they can see the Form of the Good has much in common with the passages I discuss in Phaedo and Symposium. Similarly, the Theaetetus "digression" passage (176a-b) quoted below on "becoming like God" might be interpreted similarly, since becoming like God requires us to become "just and pious, with understanding" (Plato 1997b). However, it would take much more interpretive work than this paper allows to adequately show how these passages make a similar point as the Phaedo and Symposium discussions.

3 For convincing evidence that the Cappadocians were influenced by Plotinus, refer to (Rist 1981).

$4 \quad$ Enneads 1.2.4 16. All Plotinus passages translated by Armstrong (Plotinus 1966).

$5 \quad$ All Phaedo passages translated by Sedley and Long (Plato 2010). 
6 There are several reasons why Socrates may purposely oversimplify his assessment of the body and the soul in this context. For example, it may serve to help make his point about the need for moral purification, or it may help to achieve a desired effect in his interlocutors, such as helping to cure them of their fear of death or getting them to care more for virtue and philosophy. Or, it could serve all of these purposes at once. However, a more complete analysis of this issue falls outside the scope of this paper. Ahrensdorf (1995, p. 41) suggests that Socrates makes claims about the body, soul, wisdom, and the philosopher's quest for death with a view to Simmias' conviction that "the philosopher dedicates his life to the goal of attaining a perfect or pure wisdom," which may be an erroneous assumption.

7 Socrates' claim at $67 \mathrm{~b}$ that "it is not sanctioned for someone impure to grasp something pure" confirms that one of his main emphases in the discussion from $64 \mathrm{a}-69 \mathrm{e}$ is the view that we must (at least begin) to purify ourselves before attaining truth or knowledge of the forms.

8 Gotshalk (2001, p. 33) rightly argues that Socrates is claiming here that the partial wisdom the philosopher cultivates during his bodily life allows for true virtue (and thus purification); it is the addition of wisdom that separates him from those who have the "slavish" versions of the virtues.

9 All Symposium passages are translated by Woodruff and Nehamas (Plato 1997a).

10 I follow Sheffield (2006, p. 36) in describing the the soul's transformation as it ascends the ladder as a realization of its "natural potentialities," which it could not accomplish without cultivating virtue: "All human beings carry various natural potentialities (206c1-3) which require productive work for their expression (206c1-8). Performing that work well is to express that activity in accordance with wisdom and virtue (209a3-4, c6-7), an activity best expressed in the ascent (212a1-6)".

11 Gerson (2013, pp. 289-90) appropriately highlights Plotinus' view that embodiment is ultimately the cause of vice: “... the source of human woe and wrongdoing is a failure to grasp or to grasp fully one's own true identity. That identity is found in a disembodied intellect. It is this intellect that is immortal, not the human being. It is embodiment that brings with it 'forgetfulness' and confusion about one's identity".

12 Since the Intellect "contains" all of the forms, the Intellect contemplates the forms and itself simultaneously.Plotinus claims that possessing these virtues gives the soul "likeness to God" in some sense, since the soul is "pure" and free from "bodily affections," but "the Divine itself" is ultimately not in this "state" of purity "because it has no states at all; states belong to the soul" (1.2.3. 19-24).

13 Hadot $(1989$, p. 64) succinctly summarizes Plotinus' view regarding the attainment of the higher virtues in the act of noēsis: "There is a part of ourselves which is always up above, and if, sometimes, we are fortunate enough to be raised up to this higher level, it is then that we live the best of lives. We then rest within the Divine; we are overcome by total presence, experience the love of the Good, and become an act of vision which is nothing other than the very light from which vision emanates".

According to Armstrong, n. 144, Plotinus (1966) explains the relationship between the forms of each virtue in the Intellect and virtue in souls using his principle that "the order and pattern in a lower multiplicity is always the expression of a higher unity". McGroarty (1994, p. 111) argues that it is only in this state of unification with the Intellect that humans attain genuine eudaimonia according to Plotinus: "[ ... ] eudaimonia belongs only to those who have made the ascent and actually lived this higher life. We are not 'happy all the time;' only the virtuous have eudaimonia, vide I.5.2.4 5 where eudaimonia is measured by virtue".

16 Although the Cappadocians' discussions of moral virtue seem to focus mainly on temperance and justice, Plotinus shows how all four cardinal virtues in one way or another involve detachment from the body or bodily goods, and I see no reason to believe that the Cappadocians would disagree with Plotinus on this matter. Again, refer to Rist (1981) for more on the connection between the Cappadocians and Plotinus.

17 On the Holy Spirit ch. 23, pg. 47; text from (Bradshaw 2019). All passages in this paper from the Cappadocian Fathers are contained in this anthology, which I will abbreviate as "GCT." This anthology uses the translations from The Nicene and Post-Nicene Fathers, ed. Philip Schaff and Henry Wace (orig.pub. T\&T Clark, 1886-1900).

Ibid.

On the Holy Spirit ch. 23, GCT pg. 47.

20 To settle how deification comes to an end for the Cappadocian Fathers falls outside the scope of this paper, but Gregory of Nyssa's notion of epektasis addresses this idea, as I will explain below.

21 On the Holy Spirit ch. 61 GCT pg. 48. Right after this passage, Basil also lists Biblical examples of this phenomenon of unstable character: "Examples of this are seen in Saul and the seventy elders of the children of Israel (except Eldad and Medad, with whom alone the Spirit appears to have remained), and, generally, any one similar to these in character (see I Sam. 16:13-14, Num. 11:25-29)".

22 Gregory of Nyssa gives a similar account of the soul's rejection of grace in On Virginity ch. 12, GCT pg. 56.

23 For a detailed description of Aristotle's idea that virtue is an activity (energeia) of the soul as well as the ancient reception of this idea, refer to (Bradshaw 2004).

24 On Virginity ch. 11, GCT pg. 54.

25 Scripture can play an important role in leading humans to seek purity: "Perhaps, then, the Scripture has gently led us through examples to the thought of transforming ourselves to something better than we are. It shows us that the only way for the soul to 
be attached to the incorruptible God is for it to make itself as pure as it can. When it submits itself to the purity of God, then, reflecting like a mirror, it will be given form by its participation in and reflection of the prototypal Beauty" (On Virginity ch. 11, GCT pg. 55).

"True beauty" is not measured or gauged by the senses whatsoever for Gregory, but rather by the mind, and to make his point he uses language similar to Plato's in Symposium (211a-c): "[A purified] person will love and desire that alone which has its beauty, not from another source nor in connection with the things just mentioned, but that which is beautiful of itself, through itself, and in itself; that which is always beautiful, not sometimes beautiful and sometimes not ... " (On Virginity ch. 11, GCT pg. 55). On Virginity ch. 12, GCT pg. 56.

28 For a full treatment of Gregory's writing on this topic, see (Petcu 2017).

29 We might understand this as the static, all-embracing vision of understanding that Plotinus ascribes to the intellectual act of noēsis. Compare the passages from the Cappadocians' remarks with Plotinus' description of his own noetic experience: “Often I have woken up out of the body to myself and have entered into myself, going out from all other things; I have seen a beauty wonderfully great and felt assurance that then most of all I belonged to the better part; I have actually lived the best life and come to (identity) with the divine; and set firm in it I have come to that supreme actuality, setting myself above all else in the realm of Intellect. Then after that rest in the divine, when I have come down from Intellect to discursive reasoning, I am puzzled how I ever came down, and how my soul has come to be in the body when it is what it has shown itself to be by itself, even when it is in the body" (Enneads, IV.8.1.1-13). Consult Corrigan's article "'Solitary' Mysticism in Plotinus, Proclus, Gregory of Nyssa, and Pseudo-Dionysius" (Corrigan 1996) for more on the affinity of Plotinus' and early Christian accounts of mystical experience. Oration 38: On the Theophany ch. 7, GCT pg. 52.

31 While Gregory likely borrows this imagery of light and sight from several religious and philosophical sources, a famous passage containing such imagery is, of course, the image of the sun and the cave in Plato's Republic VI and VII in (505d-523a). For analysis of Gregory of Nyssa's writings containing imagery of darkness and light to describe mystical experience, see (Martin Laird 1999, p. 594) claiming that "Gregory's so-called mysticism is no less one of light than one of darkness."

Bradshaw (2018, p. 94) characterizes human wisdom as participation in divine wisdom: “... human wisdom consists in participating in divine wisdom; that is, it consists in both seeing the world as God sees it, and responding accordingly ... to be capable of such perception and action requires appropriate moral habituation, so that wisdom cannot be gained through purely intellectual pursuits but requires a broad development of character".

35 Plass (1980, p. 181) discusses the limits imposed on humans' connection with God due to their nature as bodily creatures bound to time: "As we approach God through time we realize that we cannot actually go beyond time (i.e., aiōn). The effort to do so is like being at the edge of a sheer mountain cliff, groping hand and foot for a hold but touching nothing. Time and space vanish, yet we cannot do without them (On Ecclesiastes 412)".

\section{References}

Ahrensdorf, Peter J. 1995. The Death of Socrates and the Life of Philosophy: An Interpretation of Plato's Phaedo. Albany: SUNY Press. Bradshaw, David. 2004. Aristotle East and West. Cambridge: Cambridge University Press.

Bradshaw, David. 2018. Pagan and Christian Paths to Wisdom. In The Bright and the Good: The Connection between Intellectual and Moral Virtues. Edited by Audrey L. Anton. London: Rowman and Littlefield International.

Bradshaw, David. 2019. The Greek Christian Tradition. In Philosophy in the Middle Ages: A Multi-Cultural Reader. Edited by Bruce Foltz. New York: Bloomsbury Publishers.

Corrigan, Kevin. 1996. 'Solitary' Mysticism in Plotinus, Proclus, Gregory of Nyssa, and Pseudo-Dionysius. The Journal of Religion 76: 28-42. [CrossRef]

Foucault, Michel, Alessandro Fontana, and François Ewald. 2001. The Hermeneutics of the Subject: Lectures at the College de France 1981-1982. London: Palgrave Macmillan US.

Gerson, Lloyd P. 2013. From Plato to Platonism. Ithaca: Cornell University Press.

Gotshalk, Richard. 2001. Loving and Dying: A Reading of Plato's Phaedo, Symposium, and Phaedrus. Lanham: University Press of America.

Hadot, Pierre. 1989. Plotinus or the Simplicity of Vision. Translated by Michael Chase. Chicago: The University of Chicago Press.

Hadot, Pierre. 1995. Philosophy as a Way of Life: Spiritual Exercises from Socrates to Foucault. Translated by Michael Chase. Edited by Arnold Davidson. Oxford: Blackwell.

Hadot, Pierre. 2002. What Is Ancient Philosophy? Translated by Michael Chase. Cambridge: Harvard University Press.

Laird, Martin. 1999. Gregory of Nyssa and the Mysticism of Darkness: A Reconsideration. The Journal of Religion 79: 592-616. [CrossRef] McGroarty, Kieran. 1994. Plotinus on Eudaimonia. Hermathena 157: 103-15.

Petcu, Liviu. 2017. The Doctrine of Epektasis: One of the Major Contributions of Saint Gregory of Nyssa to the History of Thinking. Revista Portuguesa de Filosofia 73: 771-82. [CrossRef]

Plass, Paul. 1980. Transcendent Time and Eternity in Gregory of Nyssa. Vigiliae Christianae 34: 180-92. [CrossRef] 
Plato. 1997a. Symposium. In Complete Works. Translated by Paul Woodruff, and Alexander Nehemas. Edited by John M. Cooper. Indianapolis: Hackett Publishing Company.

Plato. 1997b. Theaetetus. In Complete Works. Translated by M. J. Levett, and Myles Burnyeat. Edited by John M. Cooper. Indianapolis: Hackett Publishing Company.

Plato. 2010. Meno and Phaedo. Edited by David Sedley and Alex Long. Cambridge: Cambridge University Press.

Plotinus. 1966. Enneads. 7 vols, Translated by Arthur Hilary Armstrong. Cambridge: Harvard University Press.

Rist, John M. 1981. Basil's Neoplatonism: Its Background and Nature. In Basil of Caesarea: Christian, Humanist, Ascetic. Edited by Paul Fedwick. Toronto: Pontifical Institute of Mediaeval Studies, vol. 1, pp. 137-220.

Sheffield, Frisbee C. C. 2006. Plato's Symposium: The Ethics of Desire. Oxford: Oxford University Press. 